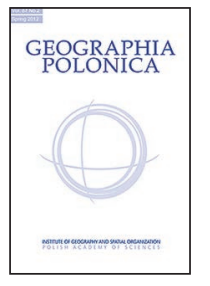

\title{
THE CHINESE MINORITY IN BUCHAREST: A CASE STUDY OF CHINESE CHILDREN RAISED AND CARED FOR BY ROMANIAN NANNIES
}

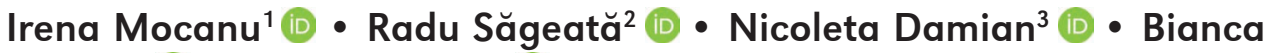 \\ Mitricắ ${ }^{4}$ (D) Mihaela Persu ${ }^{5}$ (D) \\ Institute of Geography \\ Romanian Academy \\ 12 Dimitrie Racoviță street, Bucharest-2, RO-023993, Bucharest: Romania \\ e-mails: ${ }^{1}$ mocanitai@yahoo.com • ${ }^{2}$ rsageata@gmail.com (corresponding author) • \\ ${ }^{3}$ nicoleta_damian2002@yahoo.com・biancadumitrescu78@yahoo.com・• $•{ }^{5}$ persu_mihaela@yahoo.com
}

\begin{abstract}
Since 1990, many Chinese immigrants have come to Romania. These Chinese persons are full time involved in the profitable wholesale and retail trade activities; they have families and children, cared for by Romanian nannies. The study is focused on the particularities of an intercultural dialogue, unique and recenlty highlighted in the Romanian society: between the Romanian nannies and Chinese children, located in a representative urban area for the Chinese minority. The aim of paper is to analyse how two cultures have interacted for the purpose of child care, focusing on the ways in which the life, experiences, attitudes and opportunities of Chinese children are socially and spatially shaped, influenced and structured by cultural features of the Romanian nannies.
\end{abstract}

\section{Key words}

Chinese children - Romanian nannies $\cdot$ intercultural dialogue Bucharest $\cdot$ Romania

\section{Introduction}

This paper deals with the subject of the Chinese minority (i.e. Chinese children) and the Romanian majority (i.e. the Romanian nannies who raise and care for them), and focuses on the concept of care as a topic tackled by the Children's Geographies, among other fields of research. The Children's Geographies, a sub-field of Cultural Geography, deal with the study of places and spaces of children's lives and with their specific activities (e.g. playing, learning) (Holloway \& Valentine, 2000). Furthermore, through the interaction between two different cultures (i.e. the Romanian one, on the one hand, and the Chinese one, on the other hand), the current study focuses its attention on the field of Cultural Geography, but remains oriented towards the Children's Geographies. 
Political relations between Romania, located in the Central-Eastern part of Europe, and China, the Asian country with the largest population in the world, have a long tradition, dating back to 1880 (Budura, 2018). Diplomatic relations between these two states were established in 1939 and interrupted two years later, given the geopolitical circumstances of World War II, because of the fact that Romania recognized the proJapanese government in Nanjing. They were resumed on October 5, 1949, Romania being the third country in the world officially recognizing the People's Republic of China (Government of Romania, Ministry of Foreign Affairs, 2020). The collapse of ideological barriers in Central and Eastern Europe, as well as the political openness of China starting with the 1980s, have created the premises for migratory flows between East and West, thus shaping the Chinese communities within Europe.

Under these conditions and beginning with the 1990s, many immigrants from China would come to Romania, where the Chinese community registered a significant growth, in 2011 (the year of the latest census in Romania) becoming the third-largest group of migrants (Ondreicsik, 2012) 2127 persons. However, since 1999, some unofficial estimations indicated a larger community of Chinese in Romania: e.g. Green (1998) mentioned numbers between 10,000 and 40,000 persons, while the Chinese News Agency "Xinhua" estimated, in 2004, up to 10,000 Chinese in Romania (Gao, 2004) and the Romanian newspaper "Adevărul" indicated, in 2005, numbers between 4000 and 5000 people and about 500 mixed Romanian - Chinese families (Vasiliu et al., 2005). All these estimations lead us to consider a much larger number of Chinese children in Romania (or children from mixed families), namely numbers between 1000 and 2000 Chinese. Officially, registered a total number of 1032 Chinese persons in Bucharest (51\% of total in Romania): they are dominated by the economically active persons who have families, children, and business in the city. The Chinese children number a total of 86 (Fig. 1): it seems to be a small number but it is important for researching and understanding how they are living in a city which was a foreign one for their parents but, for those born in Bucharest, this city represents 'home'.

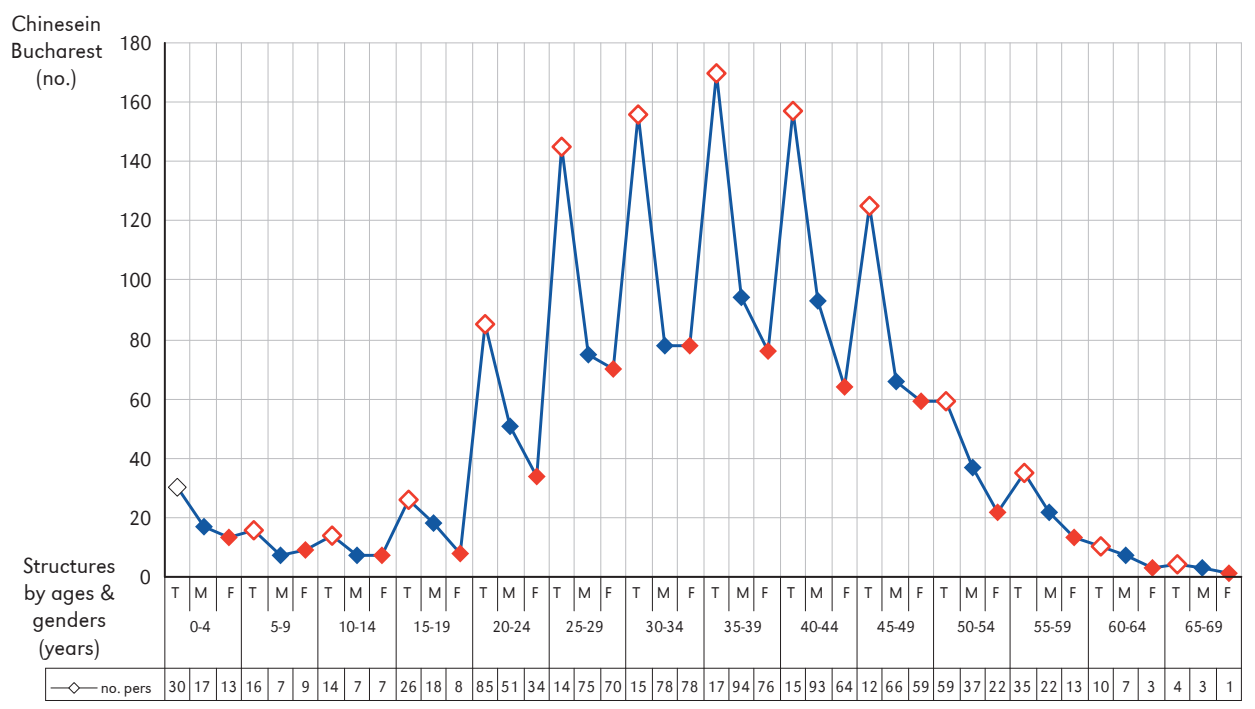

Figure 1. The Chinese minority in Bucharest City - structures by age and genders

Source: National Institute of Statistics (2011) processed data. 


\section{Background of the study}

The Chinese minority, as an investor in the Romanian economy, has piqued the interest of Romanian and foreign scientists (e.g. Păcurar, 2004; Wundrak, 2007, 2010; Nyíri, 2007; Xiao, 2010; Toader, 2011; Ondreicsik, 2012; Săgeată, 2014, 2017, Mocanu et al., 2019) in terms of its economic features and/or spatial issues stemming from said economic characteristics. On the contrary, the academic papers discussing the growing Chinese minority, as a community in Romania in general, and Bucharest, in particular, are few. More than that, the studies on the social and cultural status of Chinese families and their children have not been published thus far in Romania. The issues Chinese children face are significant (e.g. how and where they live, what their attitudes are and how their opportunities are shaped both socially and spatially by parents, nannies, education and health institutions, the role of informal playgrounds etc.) and may come to be new topics of research in the field of Romanian cultural geography.

This paper is focused on the concept of care associated with Chinese child and a certain category of women (not CapitalCity natives, a migrant during communist time from different parts of the Romania, 45-60 years old, with a low and medium-level educational background) during the post-economic crisis period.

The concept of care has changed throughout history, especially during the eras related to the development of welfare states, entailing a transfer of a part of the family responsibilities to the public system or to some particular entities or persons. Despite the diversity and complexity of care, the main relation is that between two people or entities, one being physically, financially and/or emotionally dependent on the other (Christensen \& Guldvik, 2014). The care concept is associated with women (Christensen et al., 2013), who are in competition with men in the modern and contemporary society, which is in turn marked by events such as migration, the economic crisis, and paid care work (Christensen \& Guldvik, 2014). In the literature published during the past decades, the meaning of this association between women and the concept of care is highlighted, reflecting, namely, the two opposing realities: firstly, an increasing presence of women on the official labour market and secondly, a way for making a living outside the official labour market (Andall, 2000). The present study reveals several aspects linked to the second scenario: the occupancy of an inactive category of female labour force (i.e. Romanian nannies), by capitalizing on a labour opportunity offered by certain unofficial employers (i.e. migrant Chinese parents).

In his study of migrant domestic workers, Anderson (2000) spoke about the 3 ' $C$ ' cleaning, cooking and caring -, about dirty work and about the externalization of household and care work. Many studies examined the in-home childcare activity as a part of the 3 ' $C$ ', being linked in Western societies (e.g. Adamson, 2017; Langford et al., 2017) to gender roles, migration and certain domestic services (e.g. Momsen, 2005; Moya, 2007). Other studies focus on the difficulties linked to cultural and language barriers, as well as on the impact those obstacles have on live-in employment (Karoly \& Gonzalez, 2011; Busch, 2013). These are the realities mirrored in the Western societies entertaining their own model of care consisting of the relation between two categories of people: (i) the nannies, who are migrants and an ethnic minority in and of itself; (ii) the parents (their customers), who are native to the country they find themselves in, are part of an ethnic majority and come from middle-class white families ('transnational spaces of care' according to Isaksen, 2010 \& 2012);

In terms of Anderson's work content in the 3 'C' - cleaning, cooking and caring (2000), this paper tackles the following specific situation: the care content is the result of a relationship between a native Romanian woman (the nanny) and the 'subject' of their care, which is a Chinese child, that is, a migrant 
family (a Chinese family). In this particular case, the women's work is defined by Anderson's 3 ' $C$ ', but not completely, because the Romanian nannies' work is more comprehensive. Its complexity lies in the fact that the nannies' work (or job) entails educational activities (vital for their 'subject' of care, even when this type of activity has a low complexity level) and many personal and cultural interactions (even unconsciously established ones). Despite the fact that the caretaking situation analysed in our study is different from the one portrayed by Anderson, it is quite similar to the one analysed by Souralová (2014). The parallel between the two care giving situations stems from the same historic background shared by the Czech Republic and Romania, from the resemblance of the good external relationships between the former Czech and Romanian Communist regimes on the one hand, and the Communist Asian states (i.e. Vietnam, People's Republic of China), on the other hand, as well as from the analogy between the migratory phenomena of the Communist period in the Czech Republic and in Romania alike, when the industrial urban centres attracted labour force from smaller town and rural areas.

In terms of Isaksen's 'transnational spaces of care' concept (2010 \& 2012), Souralová (2014) appreciated in her study that it is extremely limited in the case of Vietnamese immigrants who hired Czech nannies as a family strategy to raise their children. We complete her observation by adding that Isaksen's categories of persons who built the 'transnational' bridges are reversed in Souralová's case-study, as well as in ours: the parents are the migrants, and not the nannies. Souralová (2014 \& 2015) spoke about the mutual emotional attachment between the caregiver (the nanny) and the care recipient (the Vietnamese child), explained the reasons why Vietnamese families don't hire Vietnamese nannies (the Czech nanny provides Czech language skills, as well as other elements that may help children become more integrated into Czech society, facilitating a 'transmission of social and cultural capital', according to Hay and Macdonald, 2010). All these issues are considered in the context of mutual Czech-Vietnamese long-term relations and they are similar to the RomanianChinese ones, as they are analysed in detail in the paper at hand.

\section{Study subject and aims}

The most recent Romanian Census (Oct. 2011) officially registered a total number of 1032 Chinese persons in Bucharest (51\% of the total number in Romania), where those who are economically active have families, children, and businesses in the city. Chinese children number a total of 86 individuals (Fig. 1). It is a small number, but an important one for researching and understanding how they live in a city which was foreign to their parents, but which, for them, who are born in Bucharest, is synonymous with the idea of 'home'. Thus, the current paper's subject of study are not all the Chinese children living in Bucharest or within the study-area (e.g. Tei neighborhood), but those Chinese children raised and cared for by Romanian nannies, and who live in a particular area covering five streets (i.e. Nada Florilor, Brașoveni, Petre Antonescu, Grigore lonescu and Teiul Doamnei) from within the study-area. This study concerns small segments of two large cultural fields. Thus, the relevance of the object of study is not necessarily granted by its quantity (i.e. the number of Chinese children in the study), but rather by the quality, that is - the category of persons who build the cultural and interpersonal relations. Furthermore, these links established at a micro-scale help reflect and positively influence the complex interactions between two different peoples and civilizations, namely the Chinese and Romanian peoples.

In one of his academic paper, Cosgrove (1989: 119) remarks that in "the local towncentre precinct as a symbolic place... where a number of cultures meet...". The Tei neighborhood (Bucharest City) is such an urban place where two cultures meet and interact, meaning the European culture, as represented by the Romanian nannies, on the one hand, 
and the Asian culture on the other hand that is the Chinese children and their parents. Thus, the present study attempts to reinforce the current body of literature by analyzing the cultural interactions, as reflected by several social and territorial relationships regarding the Chinese children in the care of Romanian nannies. In order to highlight these relationships and their effects on both the Chinese and the Romanian parts, we have taken into account three main aims have been considered:

1. to characterize the general traits of the profession of nanny to Chinese children and the cultural challenges this entails within the study-area;

2. to study the special case of cultural interactions between the Romanian nannies and the Chinese children in the selected urban areas (i.e. Tei neighborhood, focusing on the five streets mentioned above);

3. to analyze the inter-personal relations between the Chinese children and their Romanian nannies as reflections of cultural dialogs developed between the Chinese minority and the Romanian majority.

Our approach aims to answer some specific research questions along the lines of: What are intercultural interactions in the field of food/nutrition, healthcare, education, playing and spending time actively and during different events and travels? In what way childcare provided by Romanian nannies contribute to integrating Chinese minority into the Romanian majority?

\section{Study area - a space of inter-cultural interactions}

From an administrative and statistical viewpoint, Bucharest City is divided into six sectors (Fig. 2-I). In Bucharest, the Chinese population is mainly concentrated in the 2nd Sector (the study-area within Tei neighbourhood included here), where 886 people of Chinese nationality $(85 \%$ of all those who live in the Capital city) were registered (Fig. 2-II). This part of the

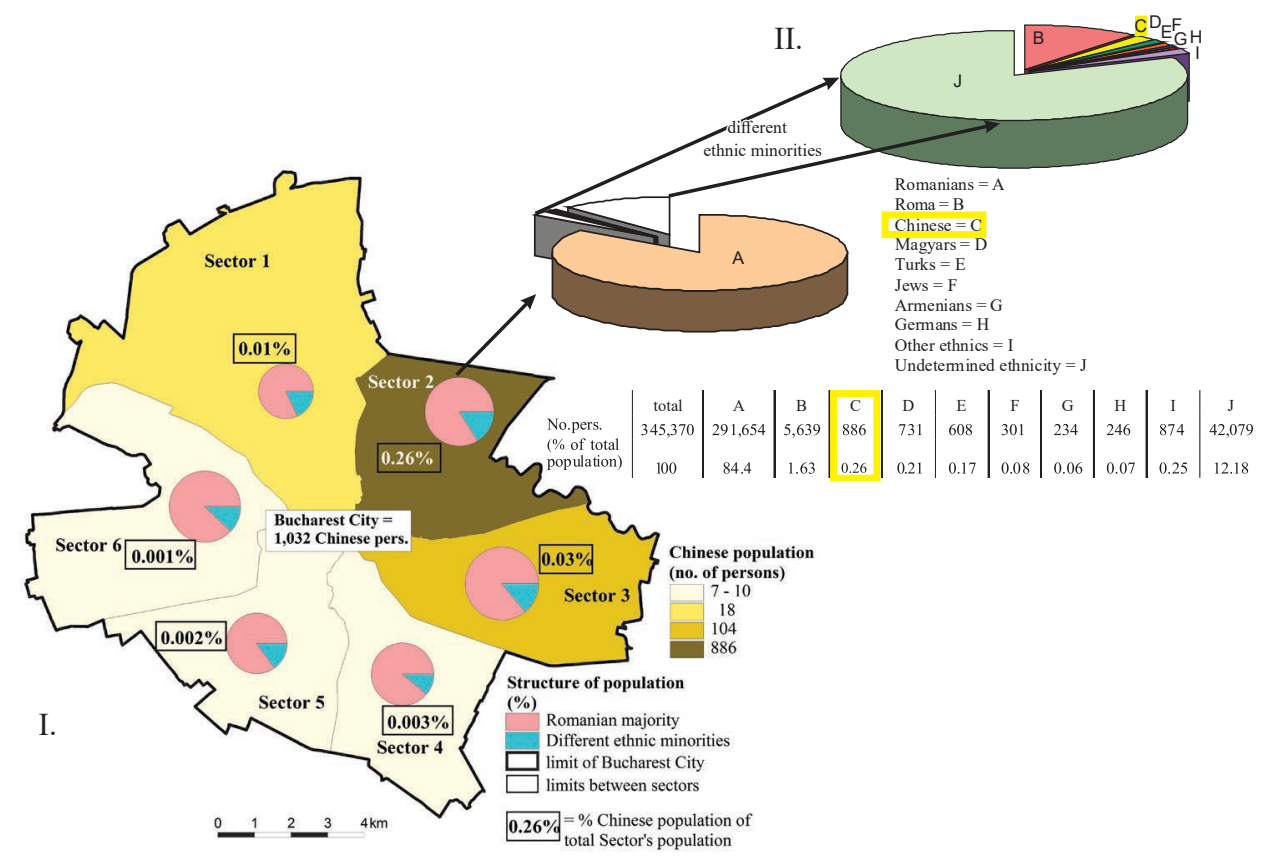

Figure 2. The majority Romanian population and the other ethnic minorities in I. Bucharest city and II. Sector 2

Source: National Institute of Statistics (2011) processed data. 


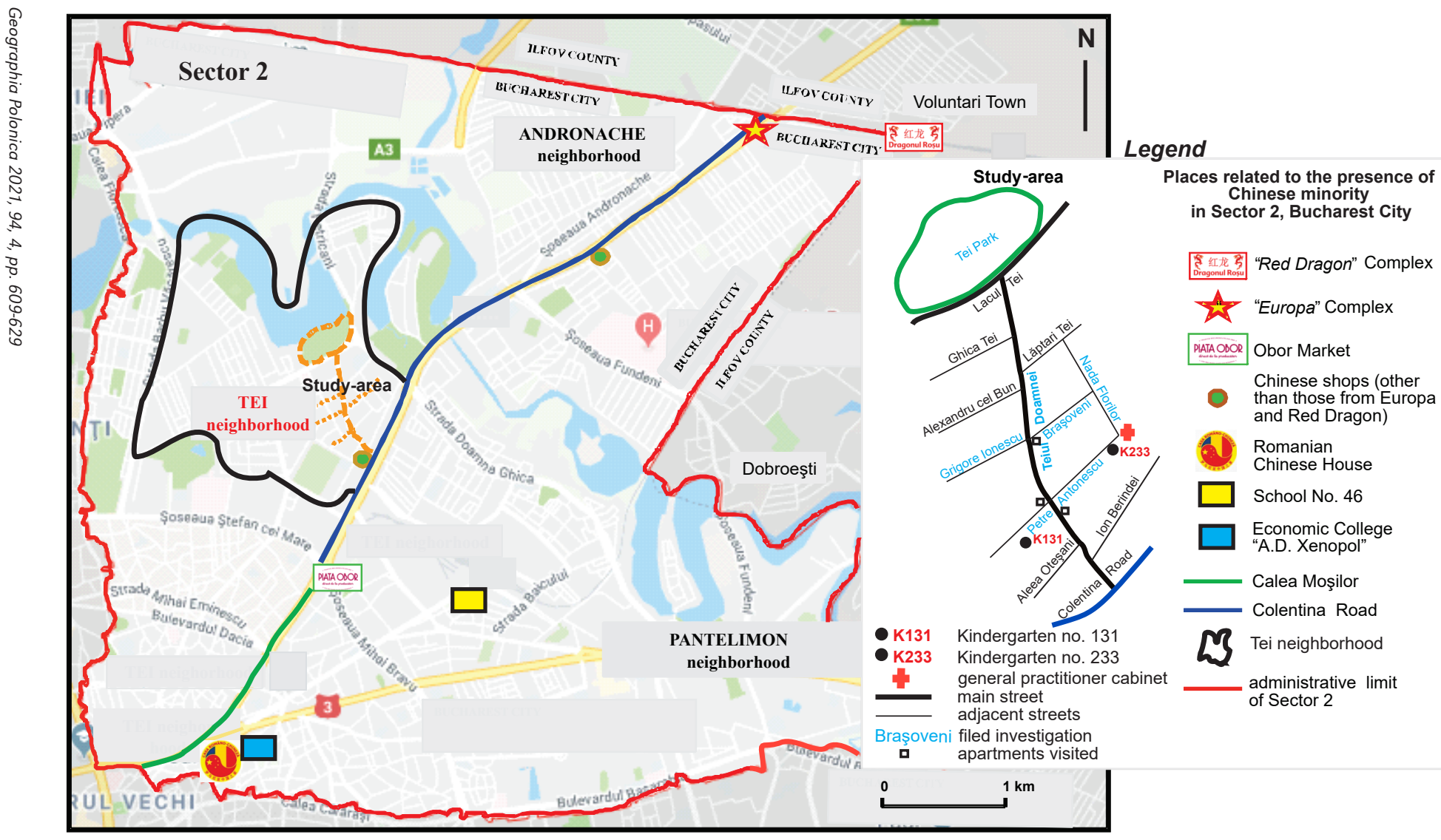

Figure 3. Location of study-area 
City stands out through the sheer number of ethnic groups, which make up $15.6 \%$ of the total population of this Sector.

Tei neighborhood is located in the $2 \mathrm{nd} \mathrm{Sec-}$ tor and has an area of $1.38 \mathrm{~km}^{2}$. Compared to other Bucharest neighbourhoods, the presence of people belonging to different ethnical minorities in public areas within Tei is not out of the ordinary. Thus, on the streets of this neighbourhood, in shops, in educational and health-care units, as well as in parks, one notices people belonging to other ethnical groups. The most numerous are the Roma and the Chinese, followed by the Muslim Arabs, Christian Arabs, and Vietnamese. However, the Romanian ethnicity remains the prevalent one.

As indicated in Fig. 3, local authorities and public institutions in the 2 nd Sector are aware of the importance of creating and maintaining social and cultural relations with the Chinese minority. Some concrete actions carried out at local administrative level show precisely this: Chinese language courses are an option for Romanian pupils in middle school (School no. 46); Chinese language is a school subject for 120 pupils (Economic College A. D. Xenopol); the existence of organizations which support cultural and economic activities and initiatives in Bucharest (e.g. The Romanian-Chinese House).

In the 2nd Sector, the economically active Chinese persons' main economic activity is wholesale and retail trade activities carried out in the Europa and Red Dragon commercial centers, located close to the 2 nd Sector.

The majority of Chinese traders have families and children, but they are very busy people, meaning that in many cases, both parents are involved in the same business, and because their economic interests involve travelling and long working hours, their children are cared for by other people. Despite the issues of non-compliance with fiscal duties (numerous cases were presented in local and central newspapers), the Chinese traders earn enough to afford an average living standard, including a Romanian nanny for their children.

\section{Data and methodology}

There is little official statistical data on the Chinese population in Bucharest (i.e. National Institute of Statistics, 2011) and the topics of the study (e.g. intercultural relations between Chinese children and their Romanian nannies and their interactions in everyday life) are not reflected in the official database at all. In view of this situation, the authors use qualitative research methods as the suitable approach when a new topic is analysed (Creswell, 2007; Corbin \& Strauss, 2008): the interview (A) and the observation (B).

(A) The main details of data gathering using the interview method within Tei neighborhood (Bucharest City) are provided in table 1.

The structured interview (1.) is quick to gather data, the interview schedule was followed exactly and the interviewer led the process (Gray, 2009). The structured interviews applied to the Romanian nanny comprised three main areas of interest, the openended questions targeting:

1.(i) the general information on the Romanian nanny, her family and household (5 questions),

1.(ii) the aspects related to the practice of the nanny profession (23 questions),

1.(iii) the cultural interactions between the Chinese children and the Romanian nannies (29 questions).

A total of 18 nannies caring for and raising Chinese children as their main occupation were identified and interviewed within the study-area in 2018, 2019 and 2020 using structured interviews.

The research was completed by unstructured interviews (2.) which follow and round up the study's objectives, as an informal or conversational interview (Gray, 2009). The non-directive interview (2.1.), as a type of unstructured interview, gathers in-depth information despite the fact that the set of questions was not pre-planned (Gray, 2009). 
In our particular case, the non-directive interviews focused on three issues:
2.1.(i) education,
2.1.(ii) healthcare,
2.1.(iii) the general opinion of locals about the Chinese minority living in $\mathrm{Te} i$ neighbourhood.

Thus, the 2.1.(i) non-directive interviews conducted with teachers and kindergarten directors aimed to find out information regarding the integration of Chinese children into a group/class of pupils; regarding the communication between teachers and Chinese parents (or Romanian nannies); the 2.1.(ii) non-directive interviews conducted with medical staff were focused on the latter's interaction with Chinese children and their parents and/or Romanian nannies, on the way in which drug treatments are accepted by Chinese parents; the 2.1.(iii) non-directive interviews with locals (e.g. residents, owners of corner stores) aim at highlighting the opinions about the presence of the Chinese population in the day-to-day life of $\mathrm{Tei}$ neighbourhood.

The non-directive interviews were conducted during the Summer and Autumn of 2019 and 2020 with four teachers and two kindergarten directors from two kindergartens located within the study-area (in Fig. 3, K233 - Kindergarten no. 233 and K131 - Kindergarten no. 131), with four medical staff members (in Fig. 3, general practitioner offices

Table 1. Data gathering using the interview method: details on the addressed issues, the targeted persons, places and gathering intervals

\begin{tabular}{|c|c|c|c|c|}
\hline $\begin{array}{c}\text { Type } \\
\text { of interview }\end{array}$ & $\begin{array}{l}\text { Issue } \\
\text { addressed }\end{array}$ & $\begin{array}{l}\text { Category } \\
\text { of targeted persons }\end{array}$ & $\begin{array}{l}\text { Institution/ } \\
\text { place for conducting } \\
\text { the interview }\end{array}$ & $\begin{array}{c}\text { Interview } \\
\text { conducting interval }\end{array}$ \\
\hline 1. structured & $\begin{array}{l}\text { 1.(i) general informa- } \\
\text { tion on the Romanian } \\
\text { nanny } \\
\text { 1.(ii) aspects related } \\
\text { to the practice of the } \\
\text { nanny profession } \\
\text { 1.(iii) cultural interac- } \\
\text { tions between the } \\
\text { Chinese children and } \\
\text { the Romanian nannies }\end{array}$ & $\begin{array}{l}18 \text { Romanian nannies } \\
\text { raising and caring for } \\
\text { Chinese children }\end{array}$ & $\begin{array}{l}\text { Romanian nan- } \\
\text { nies' households, } \\
\text { parks located within } \\
\text { Tei neighborhood or in } \\
\text { its vicinity, the studied } \\
\text { area of five streets } \\
\text { (i.e. Nada Florilor, } \\
\text { Braşoveni, Petre Anto- } \\
\text { nescu, Grigore lonescu } \\
\text { and Teiul Doamnei) }\end{array}$ & 2018,2019 and 2020 \\
\hline $\begin{array}{l}\text { 2. unstructured: } \\
\text { 2.1. non- } \\
\text { directive } \\
\text { interview }\end{array}$ & $\begin{array}{l}\text { 2.1.(i) education } \\
\text { 2.1.(ii) healthcare } \\
\text { 2.1.(iii) general opinion } \\
\text { expressed by locals } \\
\text { about the Chinese } \\
\text { minority living in Tei } \\
\text { neighbourhood }\end{array}$ & $\begin{array}{l}4 \text { teachers }+2 \text { kinder- } \\
\text { garten directors } \\
4 \text { medical personnel } \\
20 \text { locals }\end{array}$ & $\begin{array}{l}2 \text { kindergartens } \\
\text { (K233 and K131) on Pe- } \\
\text { tre Antonescu street } \\
2 \text { General Practitioner } \\
\text { offices on Nada Flo- } \\
\text { rilor street } \\
\text { The five studied } \\
\text { streets mentioned } \\
\text { under } 1 .\end{array}$ & $\begin{array}{l}\text { Summer } \\
\text { and Autumn of } \\
2019 \text { and } 2020\end{array}$ \\
\hline $\begin{array}{l}\text { 2.2. con- } \\
\text { versational } \\
\text { interviews }\end{array}$ & $\begin{array}{l}\text { 2.2. follows the issues } \\
\text { mentioned at 1.(i), 1.(ii) } \\
\text { and 1.(iii) }\end{array}$ & $\begin{array}{l}2 \text { Romanian nannies } \\
\text { raising and caring for } \\
\text { Chinese children who } \\
\text { refused to take the } \\
\text { structured interview }\end{array}$ & $\begin{array}{l}\text { Romanian nan- } \\
\text { nies' households, } \\
\text { parks located within } \\
\text { Tei neighborhood } \\
\text { or in its vicinity, the } \\
\text { five studied streets } \\
\text { mentioned under } 1 \text {. }\end{array}$ & 2018, 2019 and 2020 \\
\hline
\end{tabular}


operating in one single building located on Nada Florilor street) and twenty locals inhabiting the five studied streets (in Fig. 3, Nada Florilor, Brașoveni, Petre Antonescu, Grigore lonescu and Teiul Doamnei streets).

The authors identified two Romanian nannies caring for Chinese children who have expressed their concern about being interviewed. Thus, these nannies were part of conversational interviews (2.2.), which were created instantaneously and provided comfort (Gray, 2009), to the nannies involved. In our case, it is important to mention that, during the conversational interviews, all the issues and questions of the structured interview are followed in detail in the researcher/interviewer's mind. Thus, the information obtained through unstructured interviews (as a form of conversational interviews) of two Romanian nannies may very well complete the set of another 18 structured interviews.

(B) In this study the observation method is used: we observed the Romanian nannies, the Chinese children and other persons who interacted with them. The Romanian nannies and the Chinese children were studied in their 'natural' environment (e.g. the nanny's flat, the park), their interpersonal relations and territorial interactions being analyzed over a long period of time (2018, 2019 and 2020) within the area of study. In this study, the researchers took on two roles during the observation process: that of unobtrusive observer and that of observer-as-participant (Gorman \& Clayton, 2005; Kawulich, 2005; Baker, 2006). During the period of observation, the researchers developed relationships with the research subjects, such that they have become 'friends', a situation also quoted in literature (e.g. Adler \& Adler, 1994). According to Merriam (1998), Wolcott (2001) and DeWalt \& DeWalt (2002), in this study, the researchers followed several rules for gathering useful observation data: becoming familiar with the topic before beginning to gather data, describing the activities observed (e.g. outdoor and indoor play activities, meal time for the Chinese children) and expounding on issues of interests (e.g. the types of intercultural relationships and their physical and social means of expression). The issues of interests include relevant background

Table 2. Data gathering using the observation method: details of the issues addressed, the persons targeted, the observation places and periods

\begin{tabular}{|c|c|c|c|c|}
\hline $\begin{array}{c}\text { Type } \\
\text { of observation }\end{array}$ & Issue addressed & $\begin{array}{c}\text { Category } \\
\text { of persons targeted }\end{array}$ & $\begin{array}{c}\text { Institution/ } \\
\text { place of observation }\end{array}$ & $\begin{array}{c}\text { Period } \\
\text { of observation }\end{array}$ \\
\hline $\begin{array}{l}\text { 1. researcher } \\
\text { as an unobtrusive } \\
\text { observer }\end{array}$ & $\begin{array}{l}\text { 1.(i) playing outdoors; } \\
\text { 1.(ii) interaction } \\
\text { within the external } \\
\text { environment between } \\
\text { the Romanian nanny, } \\
\text { the Chinese child, its } \\
\text { parents, and between } \\
\text { the Chinese child } \\
\text { and other adults and } \\
\text { children; }\end{array}$ & $\begin{array}{l}\text { - Romanian nannies; } \\
\text { - Chinese children; } \\
\text { - Chinese parents; } \\
\text { - other persons } \\
\text { from other ethnic } \\
\text { groups (e.g. Arab, } \\
\text { Vietnamese) and } \\
\text { from the Romanian } \\
\text { majority; }\end{array}$ & $\begin{array}{l}\text { - parks located } \\
\text { within Tei neigh- } \\
\text { bourhood or in its } \\
\text { vicinity; } \\
\text { - streets from the } \\
\text { study area }\end{array}$ & 2018, 2019 and 2020 \\
\hline $\begin{array}{l}\text { 2. researcher } \\
\text { as an observer- } \\
\text {-as-participant }\end{array}$ & $\begin{array}{l}\text { 2.(i) playing indoors } \\
\text { and outdoors; } \\
\text { 2.(ii) interaction within } \\
\text { the external and inter- } \\
\text { nal environments be- } \\
\text { tween the Romanian } \\
\text { nanny, the Chinese } \\
\text { child and the nanny's } \\
\text { family members; }\end{array}$ & $\begin{array}{l}\text { - Romanian nannies; } \\
\text { - Chinese children; } \\
\text { - nanny's family } \\
\text { members; }\end{array}$ & $\begin{array}{l}\text { - the nanny's house; } \\
\text { - parks located } \\
\text { within Tei neigh- } \\
\text { bourhood or in its } \\
\text { vicinity }\end{array}$ & 2018,2019 and 2020 \\
\hline
\end{tabular}


information to assess interpersonal relations (e.g. within the internal environment, such as domestic spaces and the closest persons, and the external environment, such as public places and persons and the Chinese 'family far away') and their territorial interactions (e.g. the Chinese child's opportunities to travel outside of Tei neighborhood or Bucharest, accompanied by the Romanian nanny).

The main details of data gathering employing the observation method within Tei neighbourhood (Bucharest City) are presented in table 2.

During the field observation, the authors structured and wrote the field notes which have included (i) general and (ii) specific aspects:

(i) the general ones targeted the structural and organizational features in terms of consistency and social environments, the locals (ethnic minorities, the Romanian majority, their behavior outdoors, in parks, shops, in public institutions etc.) and the daily life within the neighborhood;

(ii) the specific aspects focused on the cultural interactions between the Romanian nannies and the Chinese children (e.g. the indoor spatial and functional organization of the nanny's flat, the indoor and outdoor social interactions between Romanian nannies and Chinese children, the temporal dimension of these interactions etc.).

The field notes consisted of two distinct segments (descriptive and reflective), observing several features which may be used in a useful way (e.g. accuracy, organization, focus on the research topic, recording insights and thoughts; Emerson et al., 2011; Schwandt, 2015).

\section{Results and discussions}

\section{The Romanian Nanny of Chinese Children - A New Type of Nanny}

The situation of Romanian nannies that take care of Chinese children is quite special and extremely interesting. The main classification criteria for a typological outline of nannies are:
1. the time of day when the nanny takes care of the child;

2. the duration of the childcare timeframe;

3. the nanny's living arrangements: with the child's parents, or at her own place.

The last criterion is important. Depending on it, we are able to distinguish between a 'live-in' or a 'live-out' nanny: 'in' and 'out' refer to the parents' residence (a nanny lives elsewhere, or in the parents' house).

Provided these details, we assumed that the Romanian nanny for Chinese children constitutes a new type of nanny, different from any other category of nannies known in Romania, or in Western societies. So, the Romanian nanny is not 'a night or day nanny', she is not 'a live-in full-time nanny', and neither is she 'a live-out full or part-time nanny'. She takes care of a Chinese child in her own residence (usually, a flat), the child's every-day life unfolding together with the nanny and the other members of her family; frequently, Chinese children have weekly contacts with their parents. We could define this specific type of nanny as 'a live-out of the parents' residence full-time nanny', representing the background for the future development of cultural interactions between the Romanian nannies and the Chinese children.

Chinese parents entrust their child to the Romanian nanny from a very early age. The Romanian nanny bears a great responsibility, namely to permanently supervise the child in a healthy and safe way. The Chinese parents know that this responsibility lies with a person who does not have specific childcare training (e.g. first response skills in emergency situations) and still they are sure that their child will be safe and that their specific needs will be met by the Romanian nanny. What is this certainty based on? For Chinese parents, the Romanian nanny is not an unknown person. She has very good and reliable recommendations from other Chinese families whose children have been raised by her. There is no individual labor contract concluded between the nanny and the Chinese parents, no contract for the provision of services, but there are inter-personal agreements, as well as trust. 
Legally speaking, Romanian nannies practice their profession outside the legal provisions, although the specific type of nanny is not stipulated in the Romanian legislation which specifically refers to 'daytime childcare and supervision services', while in our case nannies take care of Chinese children on a permanent (day and night) basis.

\section{Romanian Nannies - Their Families and Households}

This segment of the paper is based on the part of the interview focused on the general information on the Romanian nanny and her family, namely on the answers to 5 questions. In addition, the main information about the nannies' households was obtained following the observation process during which the authors compiled notes including specific aspects such as the features of the nannies' flats.

The interviews show that the Romanian nannies of Chinese children are not Bucharest natives, having arrived from different parts of the country during the Communist period. These women between 45 and 60 years of age have a low or medium-level educational background (generally, they have graduated from high-school, or just primary school).

The interviews revealed that all Romanian nannies for Chinese children have their own families and children (usually 2 adult children) and one or two grandchildren. So, the Chinese children are received in somewhat reliable Romanian families. In terms of the nannies' relation to the labour market and the social protection system, the interviews show that they are retired according to the Law no.2/1995, which has increased the interval of time for the anticipated retiring age from two to five years (Preda et al., 2004). This was an economically unhealthy but legally practiced method to artificially reduce (and in fact, hide) unemployment and to avoid it (i.e. the cases of Romanian nannies and many other categories of employees vulnerable to economic reorganization and reforms during the 1990s). The other members of the Romanian nannies' families hold different positions on the labour market (e.g. employee, retired, unemployed or beneficiaries of various social assistance schemes).

The nannies live in flats, of 3 or 4 rooms (average surface area of $70 \mathrm{~m}^{2}$ or nearly $90 \mathrm{~m}^{2}$, respectively), while in just two examples the apartment was a 2-room one $\left(\right.$ c. $\left.55 \mathrm{~m}^{2}\right)$. During the Communist era, these apartments were State propriety, their tenants paying a rent. After the collapse of the Communist regime, the tenant had the option of buying the apartment at a low price and paying for it in instalments; nowadays, the apartments owned are worth about 75,000-85,000 EUR on the real estate market, with a relatively high monthly maintenance cost (for winter heat consumption, hot and cold water, indoor building lighting, elevator maintenance, household waste collection charges, the common area cleaner's pay, repair costs). In many cases, this cost is difficult to bear by the nannies' families. The monthly maintenance costs are around 500-600 lei/month during winter months (i.e. 100-130 Euro/month) and the financial arrangements between the Romanian nannies and the Chinese families include these aspects, especially since the number of persons in the apartment (the Chinese child included) influences monthly maintenance costs. It is perhaps noteworthy that the nanny's adult children do not live in the same apartment as their parents (there are few situations when an adult child does not have their own house or family, and lives together with their parents). Thus, an apartment houses three or four people (the nanny, her husband, the Chinese child and, in some cases, the nanny's adult child); hence, the living space/person varies between a minimum of $17.5 \mathrm{~m}^{2} /$ person and a maximum of $30 \mathrm{~m}^{2} /$ person. Given that the World Health Organization has established a minimum of $5.5 \mathrm{~m}^{2} /$ person, we are of the opinion that the living space in these apartments is quite adequate and does not involve overcrowding. The apartments are well-equipped: one or two bathrooms, a kitchen, one or two balconies, which occasionally become an indoor 
playground for the Chinese child, or a storage space to make room in the house for arranging a playground.

\section{Main Aspects Related to the Practice of the Nanny Profession in Romania}

This section is based on the part of the interview focused on general issues related to the nanny profession, namely on the answers to 23 questions.

Romanian nannies have no preferences when it comes to taking care of a girl or a boy. There were a few cases when the first nanny job for Chinese children was filled based on a newspaper. Frequently, the job was obtained with the help of one's neighbours, or acquaintances in the neighbourhood. There is a permanent exchange of information between nannies, on the one hand, and between the Chinese families living in the study-area, on the other. Usually, Chinese children in the care of Romanian nannies were relatives. Many nannies know one another, take walks together in the park, exchange information on different childcare aspects (health status, the child's progress, etc.), inter-personal relations with the Chinese families, etc.

The Romanian nannies interviewed practiced this occupation for an average period of 10-15 years. Generally, a nanny's job for one single Chinese child lasts for about 4-5 years, on average, so during her active period in the nanny profession, she takes care of 2 or 3 Chinese children. Frequently, the nannies start with Chinese babies, about 2 to 6-month-olds (sometimes even threeweeks-olds!). This young age is motivated by the followings aspects: (i) the Chinese parents are very busy people, mother and father being involved in business; (ii) nannies say that mothers of Chinese children are "comfortable", meaning they want an agreeable life, without the many implications of caring for a child in their own home; thus, (iii) the Chinese children's mothers do not breastfeed their children and for this reason, they can involve the Romanian nannies for caring them from extremely young ages. The Romanian nannies take care of the Chinese babies until they are 4-5 years old and they go back to China. In many cases, the children are not accompanied to China by their parents, because the latter stay on in Romania to pursue their business. Additionally, the nannies are very much emotionally affected by this separation that is the child's effective departure for China. The nannies are left with keepsakes of the Chinese children (e.g. booties, baby caps, toys) and they are convinced that they have ingrained beautiful memories in the minds of the children they have cared for over the years. The Chinese children go back to China around the age of 4-5 years for several reasons detected by the authors during the research: (i) Chinese parents living in Romania are no longer required to have only one child; thus, when they become parents again, they 'release' the nanny, sending the first child to the Chinese family; (ii) some nannies express the opinion that Chinese parents do not trust the education system in Romania and therefore (iii) the child is sent to China to have time to acquire a series of essential knowledge to follow the Chinese education system (e.g. Chinese alphabet).

The Romanian nanny is involved full-time in the childcare process, but in certain cases, she is not alone in this job: other members of her family take part in it as well. There are cases when the nanny's husband is employed, but there are frequent examples where the husband is retired. In this situation, he accompanies the child on daily walks through the park. Also, in cases where the nanny's own child is an adult who lives with their parents and does not yet have a family or a job of their own, they become involved in different childcare activities (e.g. walks in the park, playtime). In the meantime, the nanny prepares the meal for the child (and for her whole family), and performs other chores, as well (e.g. cleaning, purchasing household supplies etc.).

From a very early age, the Chinese child lives in the Romanian nanny's home, together 
with her family. The child spends more than 240 days/year on average with the Romanian family). This is very important, as cultural influences are obvious and, as expected, they transfer especially from the nanny towards the Chinese child. The Romanian nannies do not speak Chinese, so the Chinese children learned Romanian through games, songs and rhymes. Nannies tell them stories and fairy-tales from Romanian folklore, or read children's literature published in Romanian (the heroes and events are from the Romanian and European culture), and last but not least, all nannies call Chinese children by Romanian names (e.g. Daniel, Mihai, Ana), or by different names derived from the Romanian pronunciation of the child's Chinese name (e.g. 'Ton-T,on'). Quite often, the nanny's family members call the child 'our doll'. Ever since Chinese children began learning their first words in Romanian, they called the nanny and her husband 'grandmother' and 'grandfather'.

Regarding the language of communication during the 4-5 year period, Chinese children speak Romanian, since their first words were in this language. Giving the Chinese children the necessary skills to communicate in Romanian, makes this language more familiar to their parents, who, generally, encounter communication problems in Romanian (which they consider to be a very difficult one). The Chinese language is not familiar to the Chinese children cared for by a Romanian nanny, because everyday life communication is in Romanian, and the people they speak with are Romanians (the nanny, her family members, friends, kindergarten teachers, etc.). Chinese children had the opportunity to learn Chinese when they visited their parents, or went to China, but these visits were too short to enable them to properly communicate in Chinese.

At first glance, the financial aspect of the relationship between the Romanian nannies and the Chinese families seems to pertain to the economic dimension alone, but there are many elements which give them enough of a cultural facet. The financial arrangements between Romanian nannies and the Chinese families are different in each case, but there are two main types of agreement:

1. the Chinese parents decide to pay a monthly sum of money, and the nanny buys everything the child needs (especially food and hygiene items; toys, clothing and footwear are brought by the parents who work in the retail trade sector);

2. the Chinese parents and the Romanian nanny decide together on a sum of money/ month for childcare expenses. Generally, the Romanian nanny presents the parents with the list of expenses.

The financial arrangements between the Romanian nannies and the Chinese families provide for some monthly maintenance fee for the nanny's flat (e.g. the Chinese family assumes part of the monthly pay for it).

None of the responding nannies had any idea about the existence of a legal framework for practicing the nanny profession. However, all the nannies who met in the study-area refused to answer those questions in the interview referring to precise summ of mony received, for fear of the fiscal authorities.

\section{Intercultural Dialogue Between the Chinese Child and Their Romanian Nannies}

This section is based on the part of the interview focused on different cultural issues (e.g. food, healthcare, education process, playtime, leisure activities, travelling, family events), which could mirror the dialog between the two cultures in question within this study, namely the answers to 29 questions.

In this study, intercultural relations are assessed from two different perspectives, in reference to the Chinese child, as they are represented in Fig. 4:

- firstly, the child's home environment maps its immediate proximity (the nanny's flat and the parents' residence - domestic places) and the closest people (the nanny and her family, and the Chinese parents); 


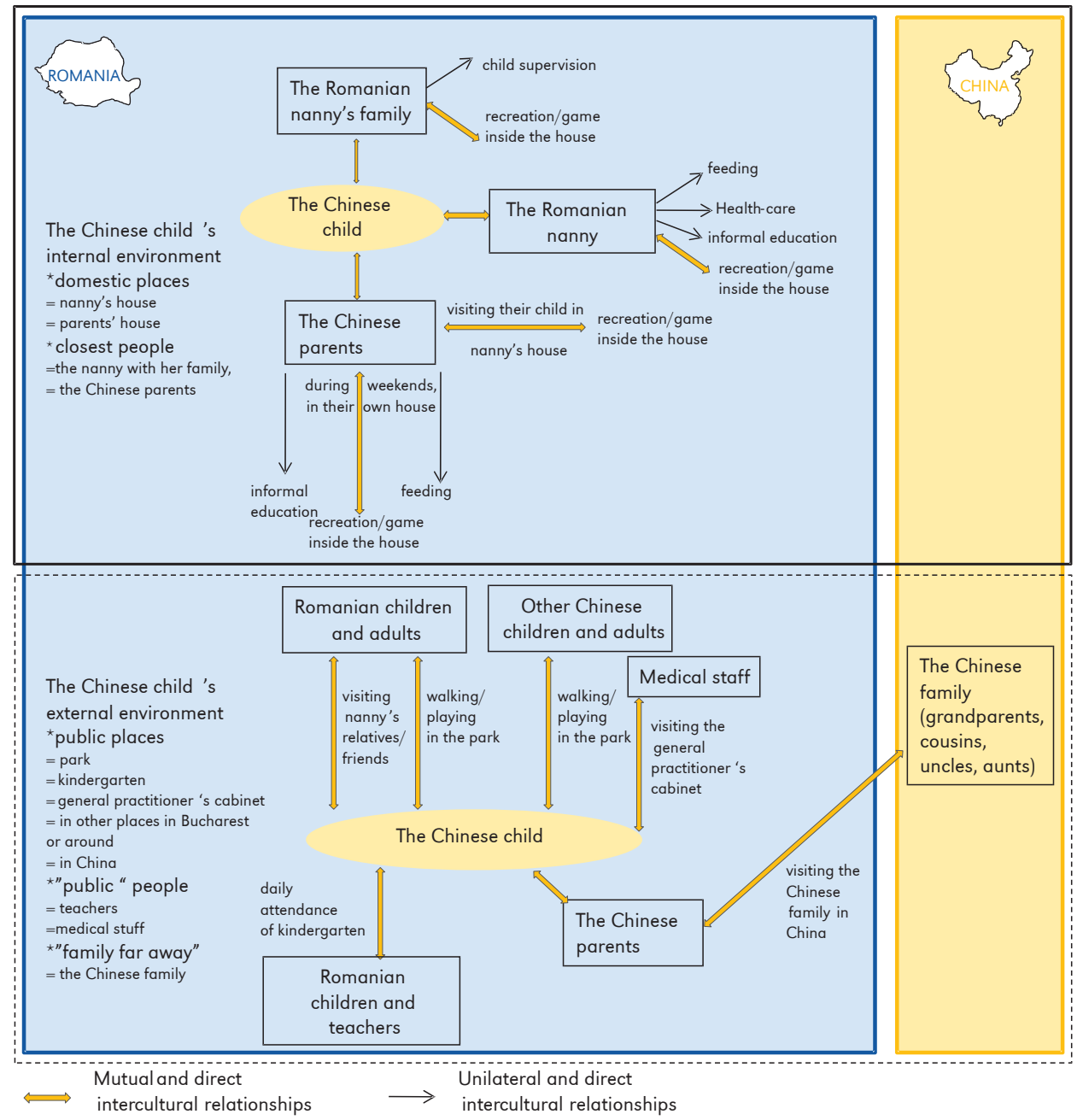

Figure 4. Romanian - Chinese cultural dialog in different environments

- secondly, the child's external environment - public places (e.g. kindergarten, parks, the general practitioners' office, various places visited by the Chinese child while in Bucharest, in Romania, or in China).

Also, the Fig. 4 presents the intercultural relations which are manifested in everyday life such as food/nutrition, healthcare, education, leisure activities, play time, special events, travelling. Thus, as already mentioned, the Romanian nannies start taking care of Chinese children when the latter are of a very young age, and a healthy nutrition is very important. Home-cooked food is perceived to be healthier, 'safer' than other dishes, because the quality of ingredients is easier to control. In Romania, home-cooked food is seen as a 'family legacy', as a practice that Romanian housewives follow, because they have been used to it since childhood. All the nannies are very good housewives, so they cook daily. Thus, the Chinese child eats fresh Romanian food every day. Frequently, ever since the child turns one, they begin to eat almost the same Romanian meals as the nanny's family members, this being a way to forge a stronger relationship between the Chinese and Romanian 'sides'. 
In diversifying the meals, the nannies include Romanian produce (the Obor market-place, the largest in Bucharest, is near the Tei neighbourhood). Another important aspect is that the nannies' parents often live in the countryside, and are small agricultural producers. They are visited by the nanny who is, in many cases, accompanied by the Chinese child, to fetch fresh agricultural products. Thus, in an era of a widespread use of geneticallymodified crops and food additives, the nanny's family (the Chinese child included) has a highly valuable (even if irregular) source of organic produce. Given that the Chinese family does not impose a specific diet, nor does it bring the nanny food or traditional Chinese products, the child is only partly familiar with Chinese food (they eat it only on the days spent with their parents). There are some cases mentioned by the interviewed nannies when the Chinese child asked the parents for Romanian traditional dishes, during the weekend-visits at their parents.

In terms of everyday life relating to healthcare and education (Fig. 4), interpersonal relations between the Chinese parents, their child and the Romanian education and healthcare providers are facilitated by the nanny. She knows the places, sometime even the very persons assigned to provide healthcare services, and last, but not least, she can easily communicate with them. Healthcare. The Chinese child is registered with a general practitioner who is part of the Romanian public healthcare system. The nanny fills in the medical file containing the required documents, she being sometimes accompanied by the child's parents. Usually, the general practitioner chosen for the child is the nanny's own family doctor. Thus, she is familiar with the medical stuff and with the medical office. In the case of a Chinese child, the doctor-patient relationship encounters no special issues compared to a regular one. If the child is ill, the nanny (alone or accompanied by the child's parents), takes them to the doctor. When ill, the nanny is fully in charge of the child, since it is she who knows him better, while the parents visit their offspring and, in some cases, become directly involved in childcare (especially, the Chinese mother, who administers the medication). There were cases (e.g. a slight irritation on the skin), a nanny recalled, when the parents did not allow her to take the child to a doctor, instead giving her a Chinese ointment to use. Education. Since Chinese children leave Romania at the age of 4 or 5 and permanently move to China, they are enrolled in the Chinese school system. The Chinese child is enrolled in kindergarten, the pre-school cycle of the Romanian public education system, the nannies being directly involved in gathering the necessary documents for enrolment, and filling in the application form. Occasionally, they are accompanied by the child's parents. The nanny takes the child daily to and from the kindergarten, takes part in parents-teacher meetings, and has conversations with the teacher regarding the child's behaviour during kindergarten activities. If there are any problems (e.g. of the disciplinary or integration kind) the nanny is to inform the parents; the other nursery children are friendly and there are no serious issues. The parents attend only two festivities: the Christmas celebration and the end of the school year graduation ceremony. Nannies did not mention communication issues, and neither did the teachers, since the Chinese children are able to communicate in Romanian just as well as their Romanian children friends. In the informal education cycle, the nanny plays the most important role, as she is constantly around the child. Day and night she consciously, or unconsciously, influences the child's behaviour and personality. Generally speaking, Chinese parents do not impose on the Romanian nanny any specific rules or behaviour approaches regarding the education of their children.

Playing and spending leisure time actively does contribute to one's mental-health development, offering opportunities for social contact (Baciu et al., 2006). Spending one's leisure time actively and playing inside and outside the nannies' or their parents' homes is the main activity Chinese children engage 
in (Fig. 4). Within the house, the child has a place of their own, playing with toys (bought by the parents) or different items used for spending leisure actively (e.g. picture books, musical toy instruments, colouring books, drawing and painting kits). All of the nanny's family members play, or spend their leisure time with the Chinese Child in an active way, but, obviously, the person most involved in these activities is the nanny herself. Seeing as the nannies know one another (often, a nanny knows at least 3-4 other nannies, and in one particular case, a nanny knew 6 other nannies caring for Chinese children), they are sometimes mutually visiting each other and in this way, the children take part in leisure activities alongside other Chinese children, learning basic social skills (e.g. social communication, cooperation, the feeling of belonging to a group). Furthermore, the majority of Romanian nannies are grandmothers and their own grandchildren would interact with the Chinese child, while the former is visiting their grandparents. Given the young age of the Chinese children, the main outdoor activity is walking and playing in the park. Nannies frequent the parks located very close to their homes (in Tei and Colentina neighbourhoods we may find two parks - Tei and Plumbuita), or in other neighbourhoods such as Obor and Circ (where there are two homonymous parks). Whatever the park, the Chinese children interact very well with other children (Romanian, Chinese, Vietnamese, etc.), as there are no issues integrating into other groups of children. Additionally, parks are places where Chinese parents spend leisure time actively, playing with their child, especially during summer weekends. In an ideal situation, Chinese parents spend 120 days/year with their child, when they visit their extended family back in China, and spend all the weekends together with the child. In reality, the interview respondents mentioned some cases where the child is left in the Romanian nanny's care while the parents leave on a visit back to China, or for many weekends when they are busy dealing with private issues.
During various Romanian and Chinese celebrations, family events and travels, Chinese parents take their offspring from the nanny's household, this being an opportunity to strengthen their relationship with their own child (Fig. 4). On Romanian holidays (e.g. Easter, Christmas), the child leaves the nanny to allow her more time to make preparations. During the Chinese holidays (e.g. the Chinese New Year), the parents and child together go to China. In most cases, children travel to China annually for two or three weeks. During these travels, the children, their parents and the extended Chinese families have mutual and direct interpersonal contact. The children come into contact with Chinese civilization and culture, with their parents' and grandparents' native country (which is not their own native country, as they are born in Romania). After the child's definitive move to China, the parents, who continue to live in Romania, keep in touch with the nanny (by phone, or by visiting her) for a certain period of time, while in many cases they are the ones who find the nanny another Chinese child to care for. In some cases, after the time spent with the parents, the Chinese child finds it somewhat difficult to reconnect with the Romanian nanny; many reverse situations occur as well, the Chinese children refusing to spend time in their parents' homes (but do agree to stay with their parents if the latter intend to visit the nanny's home!). It is obvious that the child considers the nanny's household as their own home. The interviews even reveal situations where the nannies, accompanied by the Chinese child in their care, visited said child's relatives or friends who live in other neighbourhoods in Bucharest, or in urban and rural settlements located around the Capital and in other parts of the country. Thus, the young ones interact with other Romanian adults and children in other environments than the one known by and familiar to them.

Despite the affective closeness between the Chinese child and the Romanian nanny, the latter has very little (or even incorrect) information about the child's parents. What they know is the parents' approximate 
age, where they live in Bucharest (usually in Colentina neighbourhood) and where they work in or near Bucharest (all of them owning a store in Dragonul Roșu, and Europa Commercial Centres, or in China Town, in Afumați). Nannies do not know the Chinese parents' names and have no idea about their place of origin. Also, they have no or very little information about the Chinese child's family back in China. These elements show the communication difficulties between the nanny and the Chinese parents, but also reflect discretion, or even the tendency to keep some information secret (e.g. no nanny has declared that she knows exactly where the child's parents live in Bucharest, much less in China), while parents avoid discussing their families back in China.

The main limitation of this study is the lack of the validation of results by the parents of the Chinese children, the main reason being the difficulty of addressing them due to language barriers, or their tendency towards discretion.

\section{Conclusions}

The everyday-life intercultural relationships analysed in this paper contain aspects which relate the latter's result to the theoretical background. For example, Isaksen's concept of 'transnational space of care' (2012) is mirrored in the case of Romanian nannies, as caregivers, and the Chinese children, as care recipients; their permanent relations and interactions build and shape the joining of Romanian and Chinese cultural spaces. Through this connection with Isaksen's concept of 'transnational space of care', we answer the first research question in this study and we conclude that, in the particular case of Romanian nannies and Chinese children, the 'transnational space of care' is structured on two different levels:

- the Chinese child's internal environment, shaped in domestic places (e.g. the nannies' households) and by the closest persons (e.g. the Romanian nannies, her family members);
- the Chinese child's external environment formed in public places (e.g. parks, kindergarten) and by public persons (e.g. teachers, medical personnel).

A factor responsible for the differentiation of the 'transnational space of care' consists of the fact that the permanent interactions between the Romanian nannies and the Chinese children are not balanced by the periodical and/or variable interactions between the Chinese children and their Chinese parents. The latter operate on a different frequency, duration and location, depending on the season, on their work-schedule and daily routine, etc.

This paper reveals another aspect related to the theoretical background, namely the model of in-home childcare within western societies, in which a migrant woman and a native family with one or multiple children (Greenfield et al., 2008) are involved. The care content in the specific case of our study referred to a different model, in which the roles are reversed: the relationships and interactions occur between a nanny, who is a native Romanian (as part of an ethnic majority, representing the European culture) on the one hand, and the 'subject' of their care, a Chinese child, representing a migrant Chinese family (as part of the ethnic minority, representing the Asian culture), on the other hand. Without intending and without knowing it, Chinese children and their Romanian nannies become driving forces in the active and real integration of the Chinese minority through being parts of several ordinary and actions, creating some everyday contexts and establishing interpersonal and intercultural links, which are concretised by the following facts:

- the interpersonal relationships and interactions start very early in the child's life and last a long time (about 4-5 years, with several instances where it went on for an even longer period of time, throughout the duration of their lives, emotionally speaking);

- the life of the Chinese child cared for by a Romanian nanny is spent in a Romanian 
family and in a Romanian daily life context, having direct implications on their integration process, due to the fact that they live together day and night as (grand)mother and child in the same house. The Chinese minority, through their children, is in touch with the ordinary aspects of the majority's daily living context. For the Chinese parents, the facts that their child is enrolled in Romanian education system and in the records of the Romanian healthcare system represent ways and opportunities to be in contact with the Romanian majority in terms of its institutional dimension. Despite that these institutional/'official' interpersonal relations are mediated by the Romanian nannies for facilitating the communication in Romanian language, they are added to the daily relation with majority which it entails the Chinese parents' jobs (trade).

- the Chinese children are perceived as members of their nannies' Romanian families, which is a special way in which the integration of the Chinese minority into the Romanian majority is currently happening. Being an important part of the nannies' families, who represent the Romanian majority, the Chinese children are totally involved into all the actions, situations and relations presumed by a life lived together their nannies and their families: the Chinese child eats Romanian dishes, plays and spent time with Romanian children, talks in Romanian language and travels with her/his Romanian nanny and with their family in different places from Romania. Thus, all kind of contexts and relations are established and they are lived by the Chinese child as he/she would be a member of the majority, despite the fact that he/she is a Chinese child raised and cared for by a Romanian nanny. More than that, the Chinese parents are totally dedicated to their jobs/businesses, they knowing that their children are in good hands and safe.

In terms of this in-home childcare model and relating to the second research question of the current study, we conclude that Romanian nannies, by raising and caring for the Chinese children, contribute to integrating the Chinese minority into the Romanian majority. On the other hand, it is not accidental that Chinese children are sent to China at the age of 4-5. This is the time when more intensive secondary socialization starts. So in a way it can be a tool to retain and develop their Chinese identity.

This study contributed to the Romanian Children's Geographies due to the approaches and detailed analysis of places where children live, experience playtime, and learn. In the particular case of the present paper, the children come from the Chinese minority established in Tei neighborhood (Bucharest); the places where they live are their nannies' houses; those in which they play are the indoor (i.e. some arranged or rudimentary areas inside the nannies' houses) and outdoor spaces (i.e. parks); learning and educational activities are informal (e.g. the simple educational activities such as learning colors and naming animals are carried out together with their Romanian nanny and/or with her family members) and the learning and educational processes are formal (i.e. the complex activities are performed together with teachers, in kindergarten). Thus, the contribution of this study to the Romanian Children's Geographies literature is emphasized by:

- the detailed analysis of the interior living space, as a category of space for children;

- the approach to two other categories of spaces for children during their childhood, such as the park, as a place for coming into contact with natural elements, and as an outdoor playground;

- the special interest regarding the nanny profession as practiced in connection with the Chinese children;

- the analysis of the interpersonal relationships between the Chinese children and their Romanian nannies.

From a practical perspective, the results of this study could lead to a greater transcultural understanding between the Romanian majority and the Chinese minority and, 
ultimately, to a more harmonious childrearing environment in this particular care giving situation.

The status of the Romanian nannies of Chinese children is a typical case of dialogue and interactions between representatives of two entirely different cultures, different age groups and education levels between which there existed no previous contact.

\section{Acknowledgements}

The research for this paper was conducted under the research plan of the Institute of Geography -"Geographical studies on the evolution of the ethnical structure of population in Romania after 1990". The authors contributed equally to the paper.

We thank the reviewers who through their observations contributed to improving the quality of this study.

Editors' note:

Unless otherwise stated, the sources of tables and figures are the authors', on the basis of their own research.

\section{References}

Adamson, E. (2017). Nannies, migration and early childhood education and care: An international comparaison of in-home childcare policy and practice. Bristol: Policy Press. https://doi.org/10.2307/j.ctt1t89j1z

Adler, P.A., Adler, P. (1994). Observational techniques. In N.K. Denzin, Y.S. Lincoln (Eds.), Handbook of qualitative research. (pp. 377-392), Thousand Oaks: Sage Publications.

Andall, J. (2000). Gender, migration and domestic services. The politics of Black Women in Italy. London: Routledge.

Anderson, B. (2000). Doing the dirty work? The global politics of domestic labour. London: Zed Books.

Baciu, A., Cazan, C.M., Chendea, C., Cobzariu, C., loachim, M., Mihalcea, T., Oneț, C. (2006). Educația părinților, Bucharest: Ministerul Educației și Cercetării \& MarLink. http://www.pentrueducatie.ro/upload/doc/Educa\%C5\%A3ia\%20p\%C4\%83rin\%C5\%A3ilor.pdf

Baker, L. (2006). Observation: A complex research method. Library Trends, 55(1), 171-189. https://doi.org/10.1353/lib.2006.0045

Budura, A.E. (2018). Diplomația chineză - premise istorice și cultural. Bucharest: Top Form.

Busch, N. (2013). The employment of migrant nannies in the UK: Negotiating social class in an open market for commoditised in-home care. Social \& Cultural Geography, 14(5), 541-557. https://doi.org/10.1080/14649365.2012.736528

Chinese of Romania. https://en.wikipedia.org/wiki/Chinese_of_Romania

Christensen, K., Guldvik, I. (2014). Migrant care Workers: Searching for new horizons. London: Routledge.

Christensen, K., Guldvik, I., Larsson, M. (2013). Active social citizenship: The case of disables people's rights to personal assistance. Scandinavian Journal of Disability Research, 16(S1), 19-33. http://doi.org/10.1080/15017419.2013.820665.

Corbin, J., Strauss, A. (2008). Basics of qualitative research: Techniques and procedures for developing grounded theory. 3rd edition. Thousand Oaks: Sage Publications.

Cosgrove, D. (1989). Geography is everywhere: Culture and symbolism in human landscapes. In D. Gregory, R. Walford (Eds.), Horizons in human geography (pp. 118-135). Basingstoke: Macmillan Education.

Creswell, J.W. (2007). Qualitative inquiry and research design: Choosing among five approaches. International Student Edition. Thousand Oaks: Sage Publications. 
DeWalt, K.M., DeWalt, B.R. (2002). Participant observation: A guide for fieldworkers. Walnut Creek: AltaMira Press.

Emerson, R.M., Fretz, R.I., Shaw, L. (2011). Writing ethnographic field notes. Second edition, Chicago: University of Chicago Press.

Gao, Y. (2004). Lǔjjūluōmăníyàhuárényuēyǒuyī wàn dāngdegūniáng'àijiàzhōngguónánrén (About 10,000 Chinese living in Romania. Local girls love to marry Chinese men). Xinhua News, Dec. 1. Archived from the original on 2008 Oct. 24, retrieved on 2009 April 7, Xinhua News Agency. [in Chinese]

Green, P.S. (1998). Chinese Find Romania No Land of Gold. https://www.nytimes.com/1998/12/26/business/worldbusiness/IHT-chinese-find-romania-no-land-of-gold.html

Gorman, G.E., Clayton, P. (2005). Qualitative research for the information professional. Second edition. London: Facet.

Government of Romania, Ministry of Foreign Affairs (2020). Bilateral relations. People's Republic of China - General presentation. https://www.mae.ro/bilateral-relations/3121

Gray, D.E. (2009). Doing research in the real world. Second edition. Thousand Oaks: Sage Publications.

Greenfield, P., Flores, A., Davis, H., Salimkhan, G. (2008). What happens when parents and nannies come from different cultures? Comparing the caregiving belief systems of nannies and their employers. Journal of Applied Developmental Psychology, 29(4). 326-336. https://doi.org/10.1016/j.appdev.2008.04.002

Hay, P., Macdonald, D. (2010). Evidence for the social construction of ability in physical education. Sport, Education and Society, 15(1), 1-18. https://doi.org/10.1080/13573320903217075

Holloway, S.L., Valentine, G. (Eds.). (2000). Children's geographies: Playing, living, learning. London: Routledge. https://doi.org/10.4324/9780203017524

Isaksen, L.W. (Ed.). (2010). Global care work: Gender and migration in Nordic societies. Lund: Nordic Academic Press.

Isaksen, L.W. (2012). Transnational spaces of care: Migrants nurses in Norway. Social Politics, 19(1), 58-77. https://doi.org/10.1093/sp/jxr029

Karoly, L.A., Gonzalez, G.C. (2011). Early care and education for children in immigrant families. The Future of Children, 21(1), 71-101. https://doi.org/10.1353/foc.2011.0005

Kawulich, B. (2005). Participant observation as a data collection method. Qualitative Social Research, 6(2). https://doi.org/10.17169/fqs-6.2.466

Langford, R., Albanese, P., Pretince, S. (2017). Caring for children: Social movements and public policy in Canada. Vancouver \& Toronto: UBC Press.

Merriam, S.B. (1998). Qualitative research and case study applications in education. San Francisco: Jossey-Bass Publishers.

Mocanu, I., Săgeată, R., Damian, N., Mitrică, B., Persu, M. (2019). Romanian urban areas: territorial, economic and socio-cultural hallmarks of the Chinese minority, Journal of Urban and Regional Analysis, 11(2), 185-202. https://doi.org/10.37043/JURA.2019.11.2.5

Momsen, J.H. (Ed.). (2005). Gender, migration and domestic service. London: Routledge.

Moya, J.C. (2007). Domestic service in a global perspective: Gender, migration and ethnic niches. Journal of Ethnic and Migration Studies, 33(4), 559-579. https://doi.org/10.1080/13691830701265420

National Institute of Statistics. (2011). Population and Housing Census. Bucharest. http://www.recensamantromania.ro/rezultate-2/

Nyíri, P. (2007). Chinese in Eastern Europe and Russia: A middleman minority in a transnational era. London: Routledge.

Ondreicsik, A.T. (2012). The new minority: A case study of Chinese immigrants to Romania (MA Thesis). European Studies Graduate School for Humanities, Universiteit van Amsterdam. http://arno.uva.nl/document/466797 
Păcurar, A. (2004). Noile minorități din România. Geopolitica. Revistă de Geografie Politică, Geopolitică și Geostrategie, 2(4-5), 62-72.

Preda, M., Doboș, C., Grigoraș, V. (2004). Sistemul de asigurări de pensii în România în perioada de tranziție: probleme majore și soluții, Studii de impact (PAIS II), 9, Bucharest: Institutul European din România.

Săgeată, R. (2014). Globalization and New Ethnic Minorities in Romania. In V. Mihaylov (Ed.), Territories and identities in Central, Eastern and Southeastern Europe (pp. 258-270). Częstochowa: Institute of Geopolitics.

Săgeată, R. (2017). Recent changes in Romania's ethnical structure. The Chinese Minority - A Case Study, Revue Roumaine Géographie / Romanian Journal of Geography, 61(1), 69-78.

Schwandt, T.A. (2015). How to approach writing field notes. In The SAGE Dictionary of Qualitative Inquiry. Fourth edition. Thousand Oaks: Sage Publications.

Souralová, A. (2014). Vietnamese Immigrants in the Czech Republic: Hiring a Czech Nanny as a Post-Migratory Family Settlement Strategy. In S. Hahn, S. Nadel (Eds.), Asian migrants in Europe: Transcultural connections. (pp. 95-112). Göttingen: V\&R Unipress.

Souralová, A. (2015). Mutual emotional relations in caregiving work at the turn of the twenty-first century: Vietnamese families and Czech nannies-grandmothers. In D. Hoerder, E. van Nederveen Meerkerk, S. Neusinger (Eds.), Towards a global history of domestic and caregiving workers (pp. 182-201). Boston: Brill. http://doi.org/10.1163/9789004280144_009

Toader, Ș. (2011). Cazul foștilor lucrători chinezi care au solicitat azil în România. In Străinii din România. Descrieri, analize și dialoguri pe tema imigrației. Bucharest: Blocul Național Sindical. http://www.criticatac.ro/14449/cazul-fotilor-lucrtori-chinezi-care-au-solicitat-azil-romania/

Vasiliu, A.O., Vasileanu, M., Duță, M., Covaci, T. (2005). Chinezii din România - polul est-european al civilizației asiatice. Adevărul Newspaper, August 1, https://adevarul.ro/news/societate/chineziiromania---polul-est-european-civilizatiei-asiatice-1_50abadca7c42d5a6637e5bfc/index.html

Wolcott, H.F. (2001). The art of fieldwork. Walnut Creek: AltaMira Press.

Wundrak, R. (2007). Immigration during the wild years: Chinese pioneers in Bucharest. The Romanian Journal of European Studies, 5-6, 135-151.

Wundrak, R. (2010). Die chinesische Community in Bukarest: Eine rekonstruktive, diskurs-analytische Fallstudie über Immigration und Transnationalismus. Wiesbaden: VS Verlag für Sozialwissenschaften.

Xiao, C. (2010). Souls in exile: A study of Chinese migration workers in Romania. Beijing: ILO. 